\title{
Productive performance, thermal and blood parameters of Japanese laying quails at different cage stocking densities
}

\author{
Parâmetros produtivos, térmicos e sanguíneos de codornas japonesas em postura em diferentes \\ densidade de alojamento \\ Parámetros productivos, térmico y sanguíneos de la codorniz japonesa que pone en diferentes \\ densidades de vivienda
}

Received: 03/09/2021 | Reviewed: 03/15/2021 | Accept: 03/19/2021 | Published: 03/26/2021

Venucia de Diniella dos Santos Bourdon ORCID: https://orcid.org/0000-0001-9240-7251

Universidade Federal do Tocantins, Brazil E-mail: venuciabourdonzootecnia@gmail.com

Rannyelle Gomes Souza ORCID: https://orcid.org/0000-0003-2717-0053 Universidade Federal do Tocantins, Brazil E-mail: rannyellegomes@gmail.com

Everton José do Nascimento Oliveira ORCID: https://orcid.org/0000-0001-9045-4652

Universidade Federal do Tocantins, Brazil E-mail: tobr27@yahoo.com.br

Danilo Vargas Gonçalves Vieira ORCID: https://orcid.org/0000-0002-7407-9597

Universidade Federal do Tocantins, Brazil E-mail: danilovargaszoo@ hotmail.com

Sandro Estevan Moron

ORCID: https://orcid.org/0000-0002-1359-6160

Universidade Federal do Tocantins, Brazil E-mail: sandromoron@mail.uft.edu.br

Roberta Marçal Gomes Vieira Vaz ORCID: https://orcid.org/0000-0002-5490-5492

Universidade Federal do Tocantins, Brazil

E-mail: betagmvvaz@yahoo.com.br

Kenia Rodrigues Ferreira

ORCID: https://orcid.org/0000-0002-2750-8870

Universidade Federal do Tocantins, Brazil E-mail: rodrigueskf@uft.edu.br

Liana Bezerra Dias de Lima

ORCID: https://orcid.org/0000-0002-0942-0517

Universidade Federal do Tocantins, Brazil E-mail: liana1708@uft.edu.br

Gilzelle Maria da Luz Silva

ORCID: https://orcid.org/0000-0001-5793-1082

Universidade Federal do Tocantins, Brazil E-mail: gilzelle1@hotmail.com

Josimar Santos de Almeida

ORCID: https://orcid.org/0000-0003-1379-6055

Universidade Federal do Tocantins, Brazil

E-mail: josialmeida@hotmail.com

Tadia Emanuele Stivanin

ORCID: https://orcid.org/0000-0002-1382-4573

Universidade Estadual Paulista, Brazil

E-mail: tstivanin @zootecnista.com.br

Ricardo Romão Guerra

ORCID: https://orcid.org/0000-0001-8226-8606 Universidade Federal da Paraíba, Brazil E-mail: ricardo@cca.ufpb.br

Thalita Rodrigues de Oliveira

ORCID: https://orcid.org/0000-0003-4216-2887

Universidade Federal do Tocantins, Brazil

E-mail: thalitarood@gmail.com 
Jossiel dos Santos da Cruz

ORCID: https://orcid.org/0000-0002-1928-6366 Universidade Federal do Tocantins, Brazil E-mail: jossiel.shancruz.1819@gmail.com

Fernando Guilherme Perazzo Costa ORCID: https://orcid.org/0000-0003-4075-1792 Universidade Federal da Paraíba, Brazil E-mail: perazzo63@gmail.com

\begin{abstract}
This study aimed to evaluate the effects of different stocking densities on the performance, eggshell quality, surface body temperature and hematological parameters of Japanese laying quails based on physiological indicators of animal welfare. Two hundred and thirty seven-week-old Japanese quails were used in this experiment. The quails were completely randomized to four stocking densities: 112.2 (T1), 102 (T2), 93.5 (T3), and 86.31 (T4) $\mathrm{cm}^{2} /$ quail and five replicates each. Hematological parameters were analyzed as a $4 \mathrm{x} 4$ factorial design (stocking density $\mathrm{X}$ time) over four periods of blood sampling $\left(25,50,75\right.$, and 100 days). To obtain the body surface temperature $\left(\mathrm{Ts},{ }^{\circ} \mathrm{C}\right)$ three thermograms (head, core and shin) were captured from each repetition per plot (2 repetitions per experimental plot) every 25 days ( $25,50,75$, and 100 days). Feed intake, feed conversion per egg mass, feed conversion per dozen eggs, egg mass, egg production rate, and eggshell quality-related variables were not affected by treatments. However, egg weight $(\mathrm{p}=0.023)$ and core temperature $(\mathrm{p}=0.003)$ were influenced by different cage stocking densities. The heterophil/lymphocyte ratio increased $(\mathrm{p}=0.01)$ with increasing time and stocking density. The mean corpuscular volume ( $\mathrm{p}=0.0001)$ as well as the total leukocyte count $(\mathrm{p}=0.001)$ increased until the third blood sampling period (75 days) and then decreased in the last period. Different stocking densities do not interfere with the performance and eggshell quality of Japanese quails. However, the hematological parameters and head temperature are affected by different cage stocking densities and time.
\end{abstract}

Keywords: Animal welfare; Erythrocytes; Stress; Total leukocytes; Eggshell quality; Immune system.

\title{
Resumo
}

Este estudo teve como objetivo avaliar os efeitos de diferentes densidades de alojamento no desempenho, qualidade da casca do ovo, temperatura superficial corporal e parâmetros hematológicos de codornas japonesas poedeiras com base em indicadores fisiológicos de bem-estar animal. Duzentos e trinta codornas japonesas a partir da $7^{\mathrm{a}}$ semana de idade foram utilizadas neste experimento. As aves foram divididas aleatoriamente em quatro grupos experimentais 112,2 (T1), 102 (T2), 93,5 (T3) e 86,31 (T4) $\mathrm{cm}^{2} /$ codorna de acordo com o delineamento inteiramente ao acaso, com cinco repetições. As análises hematológicas foram analisadas em esquema fatorial 4x4 (Densidade $\mathrm{x}$ Tempo) divididos em quatro períodos de coleta do sangue (25, 50, 75 e 100 dias). Para obtenção da temperatura da superfície corporal $\left(\mathrm{Ts},{ }^{\circ} \mathrm{C}\right)$ Foram capturados três termogramas (cabeça, núcleo e canela) de cada repetição por parcela (2 repetições por parcela experimental) aos $25,50,75$, and 100 dias. Consumo de ração, conversão por massa de ovos, conversão por dúzia de ovos, massa de ovos, taxa de postura das codornas e as variáveis da qualidade da casca dos ovos não apresentaram efeito entre os diferentes tratamentos, os pesos dos ovos foram influenciados pelas diferentes densidades de alojamento $(\mathrm{p}=0,023)$, assim como temperatura do núcleo da codorna $(\mathrm{p}=0.003)$. A relação heterófilo/linfócito apresentou efeito significativo $(\mathrm{p}=0,01)$, portanto pode ser afetada conforme o tempo e a densidade de alojamento for aumentado. O volume corpuscular médio $(\mathrm{p}=0,0001)$, assim como a contagem total leucocitária $(\mathrm{p}=0,001)$ aumentaram até o terceiro período de coleta $(75$ dias $)$, porém, no último período de alojamento houve decréscimo. As densidades não interferem no desempenho e na qualidade da casca dos ovos de codornas japonesas. Todavia, os parâmetros hematológicos e a temperatura da cabeça da codorna são alterados pelo tempo em função das densidades de alojamento.

Palavras-chave: Bem-estar animal; Eritrócitos; Estresse; Leucócitos totais; Qualidade da casca; Sistema imune.

\section{Resumen}

Este estudio tuvo como objetivo evaluar los efectos de diferentes densidades de vivienda en el desempeño, calidad de la cáscara de huevo, temperatura corporal superficial y parámetros hematológicos de codornices japonesas ponedoras basados en indicadores fisiológicos del bienestar animal. En este experimento se utilizaron 230 codornices japonesas de la séptima semana de edad. Las aves se dividieron aleatoriamente en cuatro grupos experimentales 112.2 (T1), 102 (T2), 93.5 (T3) y 86.31 (T4) $\mathrm{cm}^{2}$ / codorniz según el diseño completamente aleatorizado, con cinco repeticiones. Los análisis hematológicos se analizaron en un esquema factorial $4 \times 4$ (Densidad $\mathrm{x}$ Tiempo) dividido en cuatro períodos de recolección de sangre $\left(25,50,75\right.$ y 100 días). Para obtener la temperatura de la superficie corporal $\left(\mathrm{Ts},{ }^{\circ} \mathrm{C}\right) \mathrm{Se}$ capturaron tres termogramas (cabeza, núcleo y canela) de cada repetición por parcela ( 2 repeticiones por parcela experimental) a los 25, 50, 75 y 100 días. Consumo de alimento, conversión por masa de huevos, conversión por docena de huevos, masa de huevos, la tasa de puesta de codornices y las variables de calidad de la cáscara del huevo no mostraron ningún efecto entre los diferentes tratamientos, los pesos de los huevos fueron influenciados por las diferentes densidades de alojamiento ( $\mathrm{p}=0.023)$, así como la temperatura central de la codorniz $(\mathrm{p}=0,003)$. La relación 
heterófilo / linfocito tuvo un efecto significativo $(\mathrm{p}=0,01)$, por lo tanto, puede verse afectado a medida que aumenta el tiempo y la densidad de alojamiento. El volumen corpuscular medio ( $\mathrm{p}=0,0001)$, así como el recuento total de leucocitos $(\mathrm{p}=0,001)$ aumentaron hasta el tercer período de recolección ( 75 días), sin embargo, en el último período de acomodación hubo una disminución. Las densidades no interfieren con el rendimiento y la calidad de la cáscara de los huevos de codorniz japonesa. Sin embargo, los parámetros hematológicos y la temperatura de la cabeza de la codorniz se ven alterados por el tiempo en función de las densidades de alojamiento.

Palabras clave: Bienestar animal; Eritrocitos; Estrés; Leucocitos totales; Pelar la calidad; Sistema inmunológico.

\section{Introduction}

The short reproductive cycle of Japanese quails is one reason for the growing domestic production. According to Albino and Barreto (2003), quails start laying eggs around six weeks of age and continue laying until approximately 60 weeks of age.

Farmers resort to increasing stocking density in order to intensify production and profitability per area and reduce costs with equipment and cages. This common practice can lead to reduced quail performance caused by competition for space and food (Leandro et al., 2005).

Stocking density is crucial to successful quail production, i.e., it will allow determining the animal yield per area. In general, high-density stocking associated with climatic challenges, such as high temperatures, reduces livestock performance (Guimarães et al., 2014). Some authors with Albino et al. (2014) state that birds' ability to direct energy towards maintenance, weight gain, and egg production is directly associated with the environmental conditions to which they are subjected. Therefore, stressful situations, whether environmental, pathogenic, or spatial, may affect this ability.

Under heat stress condition, neuroendocrine changes occur in an attempt to resume homeothermia. The hypothalamus-pituitary-adrenal axis initiates the response through the corticotropin-releasing hormone (CRH), adrenocorticotropic hormone (ACTH) and glucocorticoid hormones. CRH is generated in the hypothalamus and depicts the mandatory stimulus to sensitize the pituitary gland to secrete $\mathrm{ACTH}$, which in turn stimulates the adrenal gland to release glucocorticoids (Dhabhar, 2009). The activation of the hypothalamus-pituitary-adrenal axis under conditions of continuous stress, therefore, increases in circulating levels of glucocorticoids, resulting in greater protein catabolism, hyperglycemia, depression, immunosuppression and increased susceptibility to infections (Matteri et al., 2000; Dhabhar, 2009; Rauw, 2012). However, the neuroendocrine changes that occur in birds under heat stress, provide changes in the immune system that are not yet well understood, because in some situations instead of immunosuppression, immunostimulation can happen (Silva et al., 2009).

Physiological changes inversely associated with well-being and increased levels of corticosterone, blood glucose, and heterophil/lymphocyte ratio (Kodaira et al., 2015) may alter feed intake, egg production rate (Vercese et al., 2012), egg weight (Pereira et al., 2008) and weaken the immune system (On Aşila \& Aksoy, 2005). On the other hand, other authors have demonstrated that stocking density does not affect the performance of Japanese quails (Lopes et al., 2006).

Physiological and behavioral indicators of stress are useful as they can be quantified and broadly fit with preconceived views of well-being (Scanes, 2016). Castilho et al. (2015) analyzed physiological and productive parameters (egg production) of laying hens under different stocking densities and reported no effect of stocking density on the studied parameters because birds have adapted themselves to that condition.

Hematology allows monitoring of general health status in livestock and evaluating the animal's ability to transport oxygen and defend against infectious agents under stress (Voigt, 2003; Schmidt et al., 2007). Blood contains specific defense cells, antibodies, and other immune system components that act as the body's defense mechanism against infections (Junqueira \& Carneiro, 2004).

Several factors may affect immune response of birds under stress, such as duration of stress exposure (acute vs. 
chronic), changes in leukocyte distribution in the body (Shini et al., 2008) and within different body compartments in which the immune response occurs, the concentration of glucocorticoids (physiological vs. pharmacological), and the nature of glucocorticoid exposure (endogenous vs. synthetic) (Dhabhar, 2009).

It is well known that stress evokes significant changes in the heterophil/lymphocyte ratio $(\mathrm{H} / \mathrm{L})$ in poultry (Davis et al., 2008). On the one hand, birds housed with reduced space show increases in circulating hemoglobin concentration (Bedánová et al., 2007). On the other hand, Fahey and Cheng (2008) reported no changes in hematological parameters and subpopulations of T lymphocytes in layers submitted to simultaneous changes in group size and cage stocking density.

This study aimed to evaluate the effects of different stocking densities on the performance, eggshell quality, surface temperature of the quail regions (head, core and shin) and hematological parameters of Japanese laying quails based on physiological indicators of animal welfare.

\section{Methodology}

This study was assessed and approved by the Ethics Committee on Animal Experimentation of the Federal University of Tocantins, Tocantins, Brazil, under the protocol n. 23101.006699/2018-16. The experiment was carried out at the Poultry Study Center of the School of Veterinary Medicine and Animal Science of the Federal University of Tocantins (UFT), Araguaína - TO, Brazil, from March 30 to August 02, 2019.

\subsection{Animals and management}

Two hundred and thirty seven-week-old Japanese quails with an initial mean body weight of $166 \pm 8.3 \mathrm{~g}$ were randomly divided into four groups with 10,11, 12, and 13 birds per experimental unit. Each group was subdivided into five replicates and submitted to the following stocking densities: 112.2 (T1), 102 (T2), 93.5 (T3), and 86.31 (T4) cm²/quail.

The quails were housed in cages with dimensions of $100 \mathrm{~cm}$ x $34 \mathrm{~cm}$ x $16 \mathrm{~cm}$ divided into three compartments of $33 \times$ $34 \mathrm{~cm}$ with an area per compartment of $1.122 \mathrm{~cm}^{2}$. Each cage was equipped with a feeder and trough-type drinker located at the cage's back and front, respectively.

During the experimental period (March/2019 to August/2019), the quails were exposed to ambient temperature conditions (subtropical) of Northern Tocantins (Table 1).

Table 1. Values of humidity, temperature and thermal amplitudes (AT) over the experimental period.

\begin{tabular}{cccccccc}
\hline \multirow{2}{*}{$\begin{array}{c}\text { Trial period } \\
\text { (days) }\end{array}$} & \multicolumn{3}{c}{ Temperature $\left({ }^{\circ} \mathrm{C}\right)$} & \multicolumn{3}{c}{ Humidity $(\%)$} \\
\cline { 2 - 7 } & Minimum & Maximum & Mean & AT & Minimum & Maximum & Mean \\
\hline Start & 22,56 & 31,59 & 27,07 & 9.0 & 68 & 97 & 80 \\
25th & 21,67 & 33,23 & 27,45 & 11.5 & 69 & 87 & 81,5 \\
50 th & 19,28 & 33,66 & 26,47 & 14.4 & 55 & 85 & 70 \\
75 th & 18,88 & 33,66 & 26,27 & 14.8 & 43 & 79 & 61 \\
100th & 18,04 & 34,93 & 26,48 & 16.9 & 40 & 77 & 58,5 \\
Mean & 19.5 & 33.9 & 26.7 & --- & 52 & 82 & 68 \\
\hline
\end{tabular}

Source: Authors.

Quails were exposed to seventeen hours of light per day. Supplemental lighting was used as needed, after nightfall $60 \mathrm{~W}$ incandescent lamps were used, for maximum egg production. the lights in the shed were on until $10 \mathrm{pm}$ (posture light program). Locally purchased diet for Japanese laying quails was provided (Table 2), according to the recommendations of the Brazilian Poultry and Swine Table (Rostagno et al, 2017). 
Table 2. Composition of the experimental diet for quails in the production phase.

\begin{tabular}{ll}
\hline Nutritional Levels (\%) & \\
\hline Metabolizable energy (Kcal / Kg) & 2,740 \\
Crude protein (\%) & 22.0 \\
Ethereal extract (\%) & 2.30 \\
Calcium (\%) & 3.15 \\
Total phosphorus (\%) & 0.67 \\
Available phosphorus (\%) & 0.45 \\
Sodium (\%) & 0.15 \\
Digestible lysine (\%) & 1.05 \\
Digestible methionine (\%) & 0.30 \\
Antioxidant (\%) & 0.10 \\
Mineral supplement ${ }^{1}(\%)$ & 1.14 \\
\hline
\end{tabular}

Enrichment per Kg offeed: Vit. A - 9.00 IU, Vit. B1 - 1.00 mg, Vit. B2 - 4.00 mg, Vit. B6 - 2 mg, Vit. B12 - 12 mcg, Vit. D3 - 2,300 IU, Vit. E - 10.00 IU, Vit. H - $30.00 \mathrm{mg}$, Vit. K3 - $1.00 \mathrm{mg}$, Folic acid - $0.20 \mathrm{mg}$, Cobalt - $5.00 \mathrm{mg}$, Copper - $10.00 \mathrm{mg}$, Choline $220.00 \mathrm{mg}$, Iron - 79.60 mg, Iodine - $1.00 \mathrm{mg}$, Manganese - $80.00 \mathrm{mg}$, Niacin - $12.50 \mathrm{mg}$, Calcium Pantothene - $5.00 \mathrm{mg}$, Selenium - $0.20 \mathrm{mg}$, Sodium - $1.47 \mathrm{~g}$, Zinc $50.00 \mathrm{mg}$. Source: Authors.

\subsection{Variables studied}

Eggs of each cage were counted and collected daily in the morning to estimate the egg production rate. Feed intake, egg production rate, egg weight, egg mass, and feed conversion per egg mass and dozen eggs were calculated at the end of every 25 experimental days. The eggs were individually weighed using a digital scale with $0.001 \mathrm{~g}$ accuracy, and then the average egg weight was calculated. Five eggs per experimental unit within the average weight range were selected for analysis of the eggshell quality (eggshell weight and thickness, and specific gravity).

Specific gravity was determined according to the methodology of Araújo and Albino (2011). The eggshells were washed under running water, oven-dried at $105^{\circ} \mathrm{C}$ for 24 hours, and weighed on a digital scale with $0.001 \mathrm{~g}$ accuracy to obtain the average eggshell weight. Eggshell thickness was determined according to Nordstrom and Ousterhout (1982).

To obtain the surface temperature of the quail regions (head, core and shin) surface temperature $\left(\mathrm{Ts},{ }^{\circ} \mathrm{C}\right.$ ) of quails, an infrared thermographic camera (Flir Systems, model Flir E60, resolution 320x240 (76.800 pixels), was used, accuracy +/- 2\% or $2{ }^{\circ} \mathrm{C}$ ). Three thermograms (head, core and shin) were captured from each repetition per plot (2 repetitions per experimental plot) every 25 days $(25,50,75$, and 100 days), $0.4 \mathrm{~m}$ away from the animals, as recommended by the manufacturer. The generated thermographic images had a resolution of 320x240 pixels, where each pixel represents a temperature point. The camera has an internal automatic temperature calibrator. An emissivity of 0.98 was considered, which is indicated by the manufacturer for biological tissues. Subsequently, these thermographic images were analyzed by the software Flir Tools ( 1.2 , to obtain the average surface temperature of each distinct body region: head, core and shin (figure 1).

Blood samples were taken as a function of time. Every 25 days (25, 50, 75, and 100 days), two birds from each replicate were randomly selected, totaling 40 birds, and blood samples $(1-1.5 \mathrm{~mL})$ were drawn using a needle and syringe by ulnar venipuncture. Blood samples were taken within 2 minutes after the initial disturbance (removal from the cage), collected into heparin-coated tubes, and stored in an icebox. Then, the samples were transferred to the laboratory for determination of heterophil/lymphocyte ratio, erythrocyte count (RBC), total leukocyte count (TLC) (Figure 2), hemoglobin (HEM), mean corpuscular volume (MCV), mean corpuscular hemoglobin (MCH), and mean corpuscular hemoglobin concentration (MCHC). 
Figure 1. Thermographic photo of the head, core and shin temperature of Japanese quail.

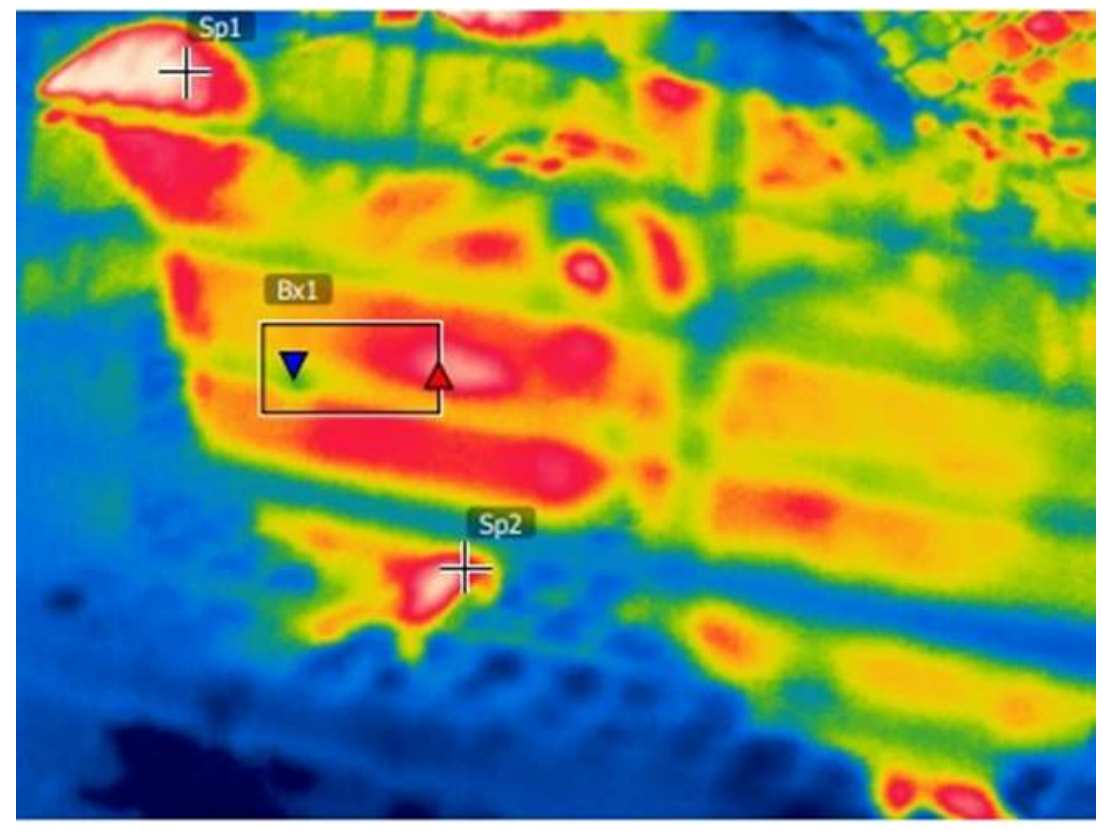

Sp1:Head,Bx1:Core, Sp2:Shin. Source: Own research.

Hematocrit level was obtained using microcapillary tubes filled with blood samples, which were sealed and centrifuged at 12,000 rpm for 5 minutes. Microhematocrit concentrations were expressed as a percentage, obtained by specific reading for the hematocrit values.

Hemoglobin estimation was performed by Drabkin's method (1948) and measured spectrophotometrically at $540 \mathrm{~nm}$ (ASYS) (Campbell, 2004).

For estimation of the total leukocyte count (Figure 2), a drop of blood was used to prepare blood smears. After drying, blood smears were fixed in methanol for 10 minutes and stained with fast panoptic stain. The total number of heterophils was divided by the total number of lymphocytes to estimate the heterophil/lymphocyte ratio (Campbell, 2004; Thrall et al., 2006). Slides were read by a single person, and subsequently, the images were captured.

The equations proposed by Coles (1984) and Campbell (2004) were used to calculate the mean corpuscular volume $(\mathrm{MCV})$, mean corpuscular hemoglobin $(\mathrm{MCH})$, and mean corpuscular hemoglobin concentration $(\mathrm{MCHC})$. 
Figure 2. Photomicrograph of Japanese quail blood distension (monocyte-arrowhead, heterophile-entire arrow, lymphocytedotted arrow, thrombotic-arrow with trace) for the total leukocyte count. Fast Panotic. 100x.

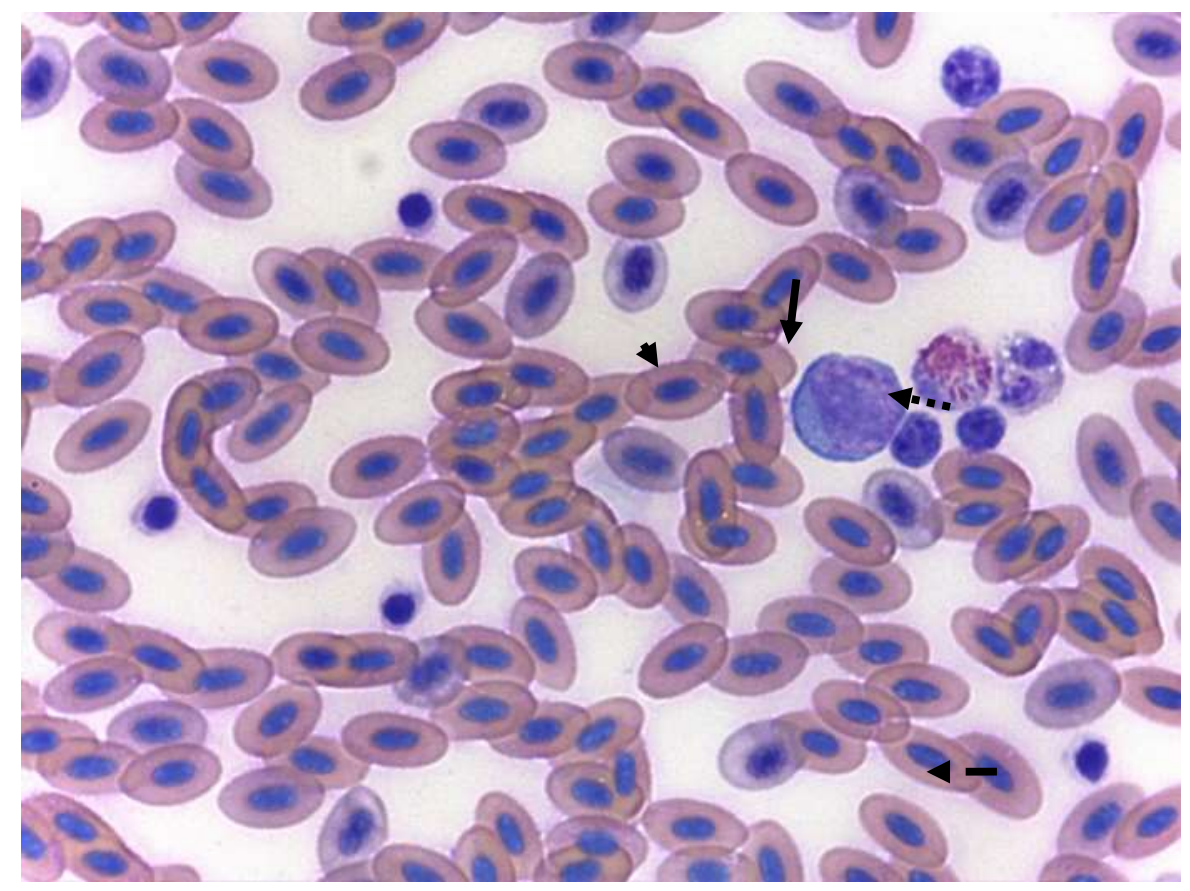

Source: Own research.

\subsection{Statistical analysis}

Errors were analyzed by the Kolmogorov-Smirnov's normality test $(\alpha=0.05)$. The homogeneity of variances was evaluated by Levene's test $(\alpha=0.05)$, and all variables showed a normal distribution of errors and homoscedasticity (SAS, 9.0, proc GLM). Then, an analysis of variance (SAS 9.0 Proc GLM; $\alpha=0.05$ ) was performed (performance, external egg quality and thermographic variables; $\alpha=0.05$ ). Hematological-related and surface temperature of the quail regions (head, core and shin) variables were analyzed as a $4 \times 4$ factorial design with four stocking densities and four blood sampling periods. The comparison of means between treatments and treatments vs. blood sampling periods was performed using Tukey's test $(\alpha=0.05)$.

\section{Results}

\section{Quail performance}

There was no significant effect of stocking density (Table 3 ) on feed intake ( $\mathrm{p}=0.974)$, feed conversion per egg mass $(\mathrm{p}=0.647)$, feed conversion per dozen eggs $(\mathrm{p}=0.937)$, egg mass $(\mathrm{p}=0.146)$, egg production rate $(\mathrm{p}=0.157)$, eggshell thickness $(\mathrm{p}=0.256)$, specific gravity $(\mathrm{p}=0.552)$, and eggshell weight $(\mathrm{p}=0.509)$. Since there were no statistical differences on the effect of housing density on the parameters mentioned above. This may have occurred due to the adaptation of the quails to the experimental environmental conditions. These results corroborate those of Lopes et al. (2006), who did not observe a significant effect of different stocking densities $\left(94.9,108.4,126.5\right.$, and $151.8 \mathrm{~cm}^{2} /$ quail) on quail performance in a 63 -day experiment.

During the whole experimental period (Table 1), the quails were exposed to temperature conditions outside the thermal comfort zone $\left(22-24^{\circ} \mathrm{C}\right.$ ), which was determined by Castro et al. (2017) in a study with Japanese laying quails. However, Soares et al. (2019) reported decreased feed intake in Japanese quails exposed to increasing temperatures (20, 24, 28, and $32^{\circ} \mathrm{C}$ ) despite no observable change in hormonal conditions ( $\mathrm{T} 3, \mathrm{~T} 4$, and corticosterona). 
Quails housed at $86.31 \mathrm{~cm}^{2} /$ quail had lower egg weight $(\mathrm{p}=0.023)$, which is similar to that observed by other researchers in studies reporting that the stocking density affected egg weight of quails (Sarica et al., 2008; El Tarabani, 2016). In the present study, eggs of quails housed at $86.31 \mathrm{~cm}^{2} /$ animal were $310 \mathrm{mg}$ lighter than eggs of quails housed at 93.5 $\mathrm{cm}^{2} /$ animal.

Table 3. Effect of stocking density under performance of quais.

\begin{tabular}{lcccccc}
\hline \multirow{2}{*}{ Parameters } & \multicolumn{3}{c}{ Density $\left(\mathrm{cm}^{2} / \mathrm{bird}\right)$} \\
\cline { 2 - 7 } & 112.2 & 102.0 & 93.5 & 86.31 & ${ }^{\dagger}$ SEM & P value \\
\hline FI & $26.81 \pm 0.64$ & $26.98 \pm 1.38$ & $27.01 \pm 0.58$ & $26.75 \pm 1.34$ & 0.472 & 0.974 \\
L & $95.82 \pm 1.18$ & $93.35 \pm 1.52$ & $95.82 \pm 2.88$ & $94.38 \pm 1.63$ & 0.856 & 0.158 \\
EW & $10.57 \pm 0.16^{\mathrm{AB}}$ & $10.75 \pm 0.21^{\mathrm{AB}}$ & $10.79 \pm 0.11^{\mathrm{A}}$ & $10.48 \pm 0.15^{\mathrm{B}}$ & 0.071 & 0.024 \\
EM & $10.13 \pm 0.20$ & $10.04 \pm 0.33$ & $10.34 \pm 0.39$ & $9.90 \pm 0.19$ & 0.130 & 0.147 \\
MCO & $2.65 \pm 0.04$ & $2.69 \pm 0.14$ & $2.62 \pm 0.13$ & $2.71 \pm 0.15$ & 0.054 & 0.648 \\
CDz & $0.336 \pm 0.01$ & $0.340 \pm 0.01$ & $0.339 \pm 0.02$ & $0.340 \pm 0.02$ & 0.005 & 0.941 \\
ST & $0,270 \pm 0.01$ & $0.268 \pm 0.01$ & $0.263 \pm 0.01$ & $0.266 \pm 0.01$ & 0.002 & 0.256 \\
SG & $1.069 \pm 0.01$ & $1.076 \pm 0.01$ & $1.073 \pm 0.01$ & $1.073 \pm 0.01$ & 0.003 & 0.552 \\
SW & $0.861 \pm 0.02$ & $0.875 \pm 0.01$ & $0.864 \pm 0.01$ & $0.865 \pm 0.01$ & 0.006 & 0.509 \\
\hline
\end{tabular}

FI: feed intake (g/quail/day), L: Laying rate (\%), EW: egg weigth (g/egg), EM: egg mass (g), MCO: Mass convertion (g/g), CDz: Dozen eggs convertion (g/dz), ST: Shell thickness, SG: Specific gravity, SW: Shell weight.

Means followed by equal letters on the same line do not differ by Tukey's test $(\alpha=0.05)$. $†$ SEM: standard error mean. Source: Authors.

\section{Temperatures of the head, body core, and shank}

There was a significant interaction between time and stocking density on head temperature $(\mathrm{p}=0.02)$. However, there was no interaction between time and stocking density on the core $(\mathrm{p}=0.198)$ and shank temperatures $(\mathrm{p}=0.658)$, although time densities alone have significantly affected core $(\mathrm{p}=0.0001)$ and shank temperatures $(\mathrm{p}=0.001)($ Table 4$)$. 
Table 4. Effect of stocking density on average temperature values $\left({ }^{\circ} \mathrm{C}\right)$ of the regions: head, core and cinnamon of laying Japanese quails.

\begin{tabular}{|c|c|c|c|c|c|}
\hline \multicolumn{6}{|c|}{ Head $\left({ }^{\circ} \mathrm{C}\right)$} \\
\hline \multirow{2}{*}{ PERIOD (days) } & \multicolumn{4}{|c|}{ Density $\left(\mathrm{cm}^{2} /\right.$ quail $)$} & \multirow{2}{*}{ MEAN } \\
\hline & 112.20 & 102.0 & 93.50 & 86.31 & \\
\hline 25 & $35.50 \pm 2,26^{\mathrm{Aa}}$ & $35.05 \pm 2,26^{\mathrm{Aa}}$ & $35.88 \pm 2,26^{\mathrm{Aa}}$ & $35.75 \pm 2,26^{\mathrm{Aa}}$ & 35.79 \\
\hline 50 & $36.50 \pm 2,26^{\mathrm{Aa}}$ & $35.48 \pm 2,26^{\mathrm{Aa}}$ & $37.15 \pm 2,26^{\mathrm{Ba}}$ & $37.30 \pm 2,26^{\mathrm{Aa}}$ & 36.61 \\
\hline 75 & $36.60 \pm 2,26^{\mathrm{Aa}}$ & $36.69 \pm 2,26^{\mathrm{Aa}}$ & $35.99 \pm 2,26^{\mathrm{Aa}}$ & $37.06 \pm 2,26^{\mathrm{Aa}}$ & 36.58 \\
\hline 100 & $35.21 \pm 2,26^{\mathrm{Cb}}$ & $35.30 \pm 2,26^{\mathrm{Bb}}$ & $34.78 \pm 2,26^{\mathrm{Cb}}$ & $36.36 \pm 2,26^{\mathrm{Aa}}$ & 35.41 \\
\hline MEAN & 35.95 & 35.88 & 35.95 & 36.62 & \\
\hline \multicolumn{6}{|c|}{ Core $\left({ }^{\circ} \mathrm{C}\right)$} \\
\hline \multirow{2}{*}{ PERIOD (days) } & \multicolumn{4}{|c|}{ Density $\left(\mathrm{cm}^{2} /\right.$ quail $)$} & \multirow{2}{*}{ MEAN } \\
\hline & 112.2 & 102 & 93.5 & 86.31 & \\
\hline 25 & $32.95 \pm 2.22$ & $32.71 \pm 2.22$ & $32.90 \pm 2.22$ & $33.28 \pm 2.22$ & $32.96^{\mathrm{A}}$ \\
\hline 50 & $33.95 \pm 2.22$ & $33.58 \pm 2.22$ & $34.71 \pm 2.22$ & $34.60 \pm 2.22$ & $34.21^{\mathrm{A}}$ \\
\hline 75 & $33.64 \pm 2.22$ & $33.11 \pm 2.22$ & $33.27 \pm 2.22$ & $34.52 \pm 2.22$ & $33.64^{\mathrm{A}}$ \\
\hline 100 & $31.18 \pm 2.22$ & $32.10 \pm 2.22$ & $32.60 \pm 2.22$ & $32.31 \pm 2.22$ & $31.80^{\mathrm{B}}$ \\
\hline MEAN & $32.93^{\mathrm{A}}$ & $32.87^{\mathrm{A}}$ & $33.12^{\mathrm{A}}$ & $33.68^{\mathrm{B}}$ & \\
\hline \multicolumn{6}{|c|}{ Shin $\left({ }^{\circ} \mathrm{C}\right)$} \\
\hline \multirow{2}{*}{ PERIOD (days) } & \multicolumn{4}{|c|}{ Density $\left(\mathrm{cm}^{2} /\right.$ quail $)$} & \multirow{2}{*}{ MEAN } \\
\hline & 112.2 & 102 & 93.5 & 86.31 & \\
\hline 25 & $35.28 \pm 3.19$ & $35.40 \pm 3.19$ & $34.80 \pm 3.19$ & $35.24 \pm 3.19$ & $35.18^{\mathrm{D}}$ \\
\hline 50 & $37.35 \pm 3.19$ & $37.92 \pm 3.19$ & $37.48 \pm 3.19$ & $38.43 \pm 3.19$ & $37.79^{\mathrm{B}}$ \\
\hline 75 & $38.54 \pm 3.19$ & $37.48 \pm 3.19$ & $37.92 \pm 3.19$ & $38.85 \pm 3.19$ & $38.20^{\mathrm{A}}$ \\
\hline 100 & $36.43 \pm 3.19$ & $37.58 \pm 3.19$ & $36.42 \pm 3.19$ & $36.88 \pm 3.19$ & $36.83^{\mathrm{C}}$ \\
\hline MEAN & $36.90^{\mathrm{D}}$ & $37.09^{\mathrm{B}}$ & $36.65^{\mathrm{C}}$ & $37.35^{\mathrm{A}}$ & \\
\hline
\end{tabular}

Different uppercase letters in the row, followed by different lowercase letters in the column differ from each other. Source: Authors.

\section{Hematological parameters}

There was a significant interaction between time and stocking density on percentages of hematocrit $(\mathrm{p}=0.0008)$, hemoglobin $(\mathrm{p}=0.009)$, mean corpuscular hemoglobin $(\mathrm{p}=0.002)$ and mean corpuscular hemoglobin concentration $(\mathrm{p}=0.02)$. However, there was no interaction between time and stocking density on heterophil/lymphocyte ratio $(\mathrm{p}=0.361)$, total leukocyte count $(\mathrm{p}=0.516)$ and mean corpuscular volume $(\mathrm{p}=0.184)$, although time significantly affected these variables (Table 5). 
Table 5. Statistics (P-value) of blood variables evaluated as a function of the collection period (days) and housing density $\left(\mathrm{cm}^{2}\right.$ / quail) for Japanese quails.

\begin{tabular}{lcccc}
\hline \multicolumn{1}{c}{ Variables } & Housing density & Collection period & Interaction & †SEM \\
\hline $\mathrm{H} / \mathrm{L}$ & 0.0451 & 0.0012 & $\mathrm{D} * \mathrm{P}$ & \\
$\mathrm{TLC}$ & 0.3550 & $<.0001$ & 0.059 & 0.059 \\
$\mathrm{MCV}$ & 0.1716 & $<.0001$ & 0.5165 & 4.311 \\
$\mathrm{RBC}$ & 0.0330 & $<.0001$ & 0.1844 & 0.042 \\
$\mathrm{HEM}$ & 0.1113 & $<.0001$ & 0.0008 & 0.464 \\
$\mathrm{MCH}$ & 0.0304 & $<.0001$ & 0.0095 & 0.088 \\
$\mathrm{MCHC}$ & 0.4492 & $<.0001$ & 0.0027 & 0.027 \\
\hline
\end{tabular}

H/L: Relationship heterophile/lymphocyte population, CTL: Total leukocyte count ( $\mu L), M C V:$ mean corpuscular volume ( $\left.\mu m^{3}\right), R_{B C}:$ hematocrit (\%), HEM: hemoglobin (g/dL), MCH: mean corpuscular hemoglobina ( pg/cell and MCHC: mean corpuscular hemoglobin concentration ( g/dL)

$D * P$ : Density*Period

SEM: standard error mean

Source: Authors.

The mean hematocrit concentrations as a function of sampling time (Table 6) were 37.38 (at 25 days), 30.75 (at 50 days), and $96.90 \%$ (at 75 days). However, at 100 days, the mean hematocrit concentration decreased to $31.89 \%$. Hematocrit concentration decreased at 50 days, increased sharply at 75 days but dropped dramatically at 100 days, regardless of the treatment.

There was no significant effect of stocking density $\left(112.2,102,93.5\right.$, and $\left.86.31 \mathrm{~cm}^{2} / q u a i l\right)$ within the blood sampling period (25, 50, and 75 days) on hematocrit concentration (Table 6). However, quails housed at 93.5 and $86.31 \mathrm{~cm}^{2} / q u a i l$ had significantly lower hematocrit concentrations at 100 days (30.95 and 28.75\%, respectively).

In the last sampling period (100 days of the experiment), the results of hematocrit concentration for quails housed at 112.2 and $102 \mathrm{~cm}^{2} /$ quail were within the reference range, which corresponds to 35 to $55 \%$ of the red cell mass. It may be related to animals' adaptation to cage size and the greater temperature range recorded in the fourth experimental period (Table 1). Hematocrit concentration increased sharply at 75 days of the experiment $(96.90 \%)$, although it did not differ between treatments. However, there was a significant difference in hematocrit levels between sampling times.

Regardless of treatment, the mean hemoglobin concentration of quails at 25 days of sampling reached $19.82 \mathrm{~g} / \mathrm{dL}$, then decreased at the second period $(11.57 \mathrm{~g} / \mathrm{dL})$, increased at 75 days of the experiment $(28.90 \mathrm{~g} / \mathrm{dL})$, and decreased again at 100 days $(11.65 \mathrm{~g} / \mathrm{dL})$. Mean hemoglobin concentrations, regardless of the sampling period, were $17.45,18.09,16.9$, and $19.5 \mathrm{~g} / \mathrm{dL}$ for quails housed at stocking densities of $112.2,102,93.5$, and $86.31 \mathrm{~cm}^{2} /$ quail, respectively. 
Table 6. Effect of the interaction between collection period and housing density on the values of hematocrit (RBC), hemoglobin (HEM), mean corpuscular hemoglobin (MCH) and concentration of mean corpuscular hemoglobin (MCHC) blood and Japanese quail laying.

\section{$\mathrm{RBC}(\%)$}

\begin{tabular}{|c|c|c|c|c|c|}
\hline \multirow{2}{*}{$\begin{array}{l}\text { PERIOD } \\
\text { (days) }\end{array}$} & \multicolumn{4}{|c|}{ Density $\left(\mathrm{cm}^{2} /\right.$ quail $)$} & \multirow{2}{*}{ MEAN } \\
\hline & 112.20 & 102.0 & 93.50 & 86.31 & \\
\hline 25 & $38.55 \pm 0.93^{\mathrm{Ab}}$ & $36.45 \pm 0.93^{\mathrm{Ab}}$ & $37.47 \pm 0.93^{\mathrm{Ab}}$ & $37.03 \pm 0.93^{\mathrm{Ab}}$ & $37.38 \pm 2.23$ \\
\hline 50 & $30.05 \pm 0.93^{\mathrm{Ac}}$ & $32.18 \pm 0.93^{\mathrm{Ab}}$ & $28.93 \pm 0.93^{\mathrm{Ac}}$ & $31.85 \pm 0.93^{\mathrm{Ac}}$ & $30.75 \pm 2.57$ \\
\hline 75 & $96.30 \pm 0.93^{\mathrm{Aa}}$ & $97.00 \pm 0.93^{\mathrm{Aa}}$ & $96.85 \pm 0.93^{\text {Аa }}$ & $97.45 \pm 0.93^{\text {Aa }}$ & $96.90 \pm 0.77$ \\
\hline 100 & $31.95 \pm 0.93^{\mathrm{ABc}}$ & $35.90 \pm 0.93^{\mathrm{Ab}}$ & $30.95 \pm 0.93^{\mathrm{Bc}}$ & $28.75 \pm 0.93^{\mathrm{Bc}}$ & $31.89 \pm 3.47$ \\
\hline MEAN & $49.21 \pm 28.18$ & $50.38 \pm 27.70$ & $48.55 \pm 28.85$ & $48.77 \pm 29.06$ & \\
\hline \multicolumn{6}{|c|}{$\operatorname{HEM}(\mathrm{g} / \mathrm{dL})$} \\
\hline \multirow{2}{*}{$\begin{array}{l}\text { PERIOD } \\
\text { (days) }\end{array}$} & \multicolumn{4}{|c|}{ Density $\left(\mathrm{cm}^{2} /\right.$ quail $)$} & \multirow{2}{*}{ MEAN } \\
\hline & 112.2 & 102 & 93.5 & 86.31 & \\
\hline 25 & $17.62 \pm 1.55^{\mathrm{Aa}}$ & $19.53 \pm 1.55^{\mathrm{Aa}}$ & $19.06 \pm 1.55^{\mathrm{Aa}}$ & $23.08 \pm 1.55^{\mathrm{Ab}}$ & $19.82 \pm 4.67$ \\
\hline 50 & $12.63 \pm 1.55^{\mathrm{Aa}}$ & $10.32 \pm 1.55^{\mathrm{Ab}}$ & $11.28 \pm 1.55^{\mathrm{Ab}}$ & $11.99 \pm 1.55^{\mathrm{Ac}}$ & $11.57 \pm 1.81$ \\
\hline 75 & $27.90 \pm 1.55^{\mathrm{Aa}}$ & $27.08 \pm 1.55^{\mathrm{Aa}}$ & $26.82 \pm 1.55^{\text {Аa }}$ & $33.79 \pm 1.55^{\text {Аа }}$ & $28.90 \pm 4.63$ \\
\hline 100 & $11.59 \pm 1.55^{\mathrm{Ba}}$ & $15.43 \pm 1.55^{\mathrm{Aa}}$ & $10.45 \pm 1.55^{\mathrm{Cb}}$ & $9.13 \pm 1.55^{\mathrm{Cc}}$ & $11.65 \pm 3.65$ \\
\hline MEAN & $17.45 \pm 6.99$ & $18.09 \pm 7.29$ & $16.9 \pm 7.71$ & $19.5 \pm 10.44$ & \\
\hline
\end{tabular}

$\mathrm{MCH}(\mathrm{pg} / \mathrm{cel})$

\begin{tabular}{|c|c|c|c|c|c|}
\hline \multirow{2}{*}{$\begin{array}{l}\text { PERIOD } \\
\text { (days) }\end{array}$} & \multicolumn{4}{|c|}{ Density $\left(\mathrm{cm}^{2} /\right.$ quail $)$} & \multirow{2}{*}{ MEAN } \\
\hline & 112.2 & 102 & 93.5 & 86.31 & \\
\hline 25 & $0.692 \pm 0.10^{\mathrm{Aa}}$ & $0.892 \pm 0.10^{\mathrm{Aa}}$ & $0.692 \pm 0.10^{\mathrm{Aa}}$ & $0.962 \pm 0.10^{\mathrm{Aa}}$ & $0.809 \pm 0.20$ \\
\hline 50 & $0.502 \pm 0.10^{\mathrm{Ab}}$ & $0.446 \pm 0.10^{\mathrm{Ab}}$ & $0.520 \pm 0.10^{\mathrm{Aa}}$ & $0.620 \pm 0.10^{\mathrm{Aa}}$ & $0.522 \pm 0.10$ \\
\hline 75 & $1.04 \pm 0.10^{\mathrm{Aa}}$ & $0.822 \pm 0.10^{\mathrm{Aa}}$ & $0.782 \pm 0.10^{\mathrm{Aa}}$ & $1.060 \pm 0.10^{\mathrm{Aa}}$ & $0.926 \pm 0.32$ \\
\hline 100 & $0.906 \pm 0.10^{\mathrm{Aa}}$ & $1.290 \pm 0.10^{\mathrm{Ba}}$ & $0.626 \pm 0.10^{\mathrm{Aa}}$ & $0.684 \pm 0.10^{\mathrm{Aa}}$ & $0.876 \pm 0.36$ \\
\hline MEAN & $0.785 \pm 0.31$ & $0.862 \pm 0.37$ & $0.655 \pm 0.21$ & $0.831 \pm 0.28$ & \\
\hline \multicolumn{6}{|c|}{$\mathrm{MCHC}(\mathrm{g} / \mathrm{dL})$} \\
\hline \multirow{2}{*}{$\begin{array}{l}\text { PERIOD } \\
\text { (days) }\end{array}$} & \multicolumn{4}{|c|}{ Density $\left(\mathrm{cm}^{2} /\right.$ quail $)$} & \multirow{2}{*}{ MEAN } \\
\hline & 112.2 & 102 & 93.5 & 86.31 & \\
\hline 25 & $45.79 \pm 3.55^{\mathrm{Aa}}$ & $53.31 \pm 3.55^{\mathrm{Aa}}$ & $51.07 \pm 3.55^{\mathrm{Aa}}$ & $62.41 \pm 3.55^{\mathrm{Ba}}$ & $53.14 \pm 12.46$ \\
\hline 50 & $42.14 \pm 3.55^{\mathrm{Aa}}$ & $32.11 \pm 3.55^{\mathrm{Ab}}$ & $39.08 \pm 3.55^{\mathrm{Aa}}$ & $37.82 \pm 3.55^{\mathrm{Ab}}$ & $37.79 \pm 6.18$ \\
\hline 75 & $29.00 \pm 3.55^{\mathrm{Aa}}$ & $27.92 \pm 3.55^{\mathrm{Ab}}$ & $27.70 \pm 3.55^{\mathrm{Ab}}$ & $34.67 \pm 3.55^{\mathrm{Ab}}$ & $29.82 \pm 4.75$ \\
\hline 100 & $36.28 \pm 3.55^{\mathrm{Aa}}$ & $42.98 \pm 3.55^{\mathrm{Aa}}$ & $34.01 \pm 3.55^{\mathrm{Aa}}$ & $31.79 \pm 3.55^{\mathrm{Ab}}$ & $36.26 \pm 8.67$ \\
\hline MEAN & $38.3 \pm 7.66$ & $39.08 \pm 13.73$ & $37.96 \pm 12.55$ & $41.67 \pm 13.64$ & \\
\hline
\end{tabular}

Different uppercase letters in the row, followed by different lowercase letters in the column differ from each other. Source: Authors. 
The effect of sampling time on hemoglobin concentrations for each experimental treatment $(112.2,102,93.5$, and 86.31 $\mathrm{cm}^{2} /$ quail) was similar to that of hematocrit concentration (Table 6).

There was a significant interaction between sampling time and stocking density on mean corpuscular hemoglobin $(\mathrm{p}=0.002)$.

There was a significant interaction between sampling time and stocking density on mean corpuscular hemoglobin concentration $(\mathrm{p}=0.02)$.

A significant difference was observed $(\mathrm{p}=0.001)$ for heterophil/lymphocyte ratio $(\mathrm{H} / \mathrm{L})$, as shown in Table 5 .

\subsection{Discussion}

Dantzer and Kelly (1989) suggested that stress suppresses gonadotropin-releasing hormone pulse generator activity. In turn, it compromises the reproductive functions of the axis due to impaired secretion of follicle-stimulating and luteinizing hormones in laying birds, which may compromise egg size.

In the present study, the quails were able to maintain physiological homeostasis to the point that the stress caused by the reduced space due to high density $\left(86.31 \mathrm{~cm}^{2} /\right.$ quail) was not enough to elicit competition between birds, which could somehow affect the evaluated parameters. Although a significant difference in egg weight was observed, this difference between the heaviest and lightest egg weight was only $0.3 \mathrm{~g}$ on average.

In animals, corticosterone levels are influenced by stress (Quinteiro Filho et al., 2010; Shini et al., 2010; Calefi et al., 2014), particularly by temperature (Soares et al., 2019). However, the short evaluation period (100 experimental days), adaptation to adaptation to housing density and ad libitum feed offer may not have been sufficient to alter corticosterone concentration because quails housed at the highest $\left(86.31 \mathrm{~cm}^{2} /\right.$ quail $)$ and lowest stocking densities $(112.2 \mathrm{~cm} /$ quail $)$ showed similar feed intake, and subsequently, egg production rate, feed conversion per mass and per dozen eggs.

These findings differ from those of Lima et al. (2012), who tested different stocking densities (121.4, 106.2, 94.4, and $85 \mathrm{~cm}^{2} /$ quail) for Japanese laying quails. The authors reported a significant effect of stocking density on feed intake, egg weight, feed conversion by egg mass, and feed conversion by dozen eggs. Moreover, Lima et al. (2012) observed that quails housed at $85 \mathrm{~cm}^{2} /$ quail had lower feed intake and egg weight.

It is known that egg-laying poultry exposed to increasing stocking density may experience thermal stress and reduced capacity to dissipate heat. Therefore, birds tend to distance themselves from each other to maximize sensible heat loss. Birds use mechanisms of physiological regulation such as increased respiratory rate during eggshell formation in the uterus, with a consequent increase in $\mathrm{CO}_{2}$ loss and then reduced availability of carbonate ions $\left(\mathrm{HCO}_{3}\right)$. Therefore, although calcium is available, eggshell quality decreases. However, quails housed at high stocking densities $\left(86.31 \mathrm{~cm}^{2} /\right.$ quail $)$ had similar results for eggshell thickness, eggshell weight, and specific gravity compared with quails housed at lower stocking densities.

On the one hand, Soares et al. (2018) reported no significant differences for eggshell thickness, specific gravity, and eggshell weight in Japanese quails housed at different stocking densities (121.43, 106.25, 94.44, and $85.00 \mathrm{~cm}^{2} /$ quail). On the other hand, Vercese et al. (2012) reported increased respiratory rate and decreased eggshell strength in Japanese quails exposed to temperatures above $21^{\circ} \mathrm{C}$. Moreover, the eggshell thickness was reduced when birds were exposed to temperatures above $27^{\circ} \mathrm{C}$. This response was not observed in this study, although birds were exposed to conditions of moderate stress (Soares et al., 2019) with temperatures reaching $27^{\circ} \mathrm{C}$ and maximum amplitude of $14.78^{\circ} \mathrm{C}$.

Given that the mean minimum temperatures were around $19.5^{\circ} \mathrm{C}$ and the light was turned off at 10 p.m. (lighting program), the quails may have changed the feed intake pattern (Pereira et al., 2013; Guimarães et al., 2014), with more feeding activities during the evening. It may explain the lack of difference in animal performance and eggshell quality. Owing to nighttime food compensation 
The means for head temperature as a function of time decreased at 100 days of the experiment $(35.21,35.30,34.78$ and $36.36{ }^{\circ} \mathrm{C}$ ). It indicates adaptation to temperature conditions in the last period, which averaged $26.7{ }^{\circ} \mathrm{C}$ (Table 1). When quails are not under heat stress, this area remains in thermal homeostasis. In a temperature mapping study using infrared thermography in Japanese quails, Souza Júnior et al. (2013) concluded that the region of the head had higher surface temperature than the other regions analyzed.

Quails housed at the highest stocking density $\left(86.31 \mathrm{~cm}^{2} /\right.$ quail $)$ had the highest head temperature $\left(36.36^{\circ} \mathrm{C}\right)$ at the end of the experimental period compared with quails housed at $112.20 \mathrm{~cm}^{2} /$ quail $\left(35.21^{\circ} \mathrm{C}\right), 102 \mathrm{~cm}^{2} /$ quail $\left(35.30^{\circ} \mathrm{C}\right)$, and 93.5 $\mathrm{cm}^{2} /$ quail $\left(34.78^{\circ} \mathrm{C}\right)$. High-density stocked quails released more heat than quails with smaller cage space due to heat stress. During periods of heat stress, featherless areas such as comb, wattles, and shins are typically vasodilated (Richards, 1971; Hillman et al., 1982). According to Dahlke et al. (2005), the comb, wattle, and shinks' total surface area correspond to $16 \%$ of the total body surface, which confirms the importance of these body regions to heat dissipation. This result corroborates the findings for mean core $\left(33.68^{\circ} \mathrm{C}\right)$ and shin temperatures $\left(37.35^{\circ} \mathrm{C}\right)$ in quails housed at the highest stocking density $(86.31$ $\mathrm{cm}^{2} /$ quail).

Regardless of sampling time, the mean hematocrit concentrations were 49.21, 50.38, 48.55, and 48.77\%, respectively, for quails housed at 112.2, 102, 93.5, and $86.31 \mathrm{~cm}^{2}$ /quail. It demonstrates hematocrit-related physiological changes in quails under conditions of moderate stress, particularly thermal amplitudes throughout the experimental period (Table 1). However, these physiological changes did not negatively affect performance (Table 3). On the other hand, Rosa et al. (2011) observed increased hematocrit concentration in Japanese quails under thermal stress.

The analysis of the isolated effects of each experimental treatment and sampling time revealed that the stress caused by the high population density in the cages was able to affect hematocrit concentration. There was no significant difference in hematocrit concentration at 100 and 50 days of sampling for quails housed at $112.2 \mathrm{~cm}^{2} /$ quail (31.95 and 30.05\%), 93.50 $\mathrm{cm}^{2} /$ quail (30.95 and $28.93 \%$ ), and $86.31 \mathrm{~cm}^{2} /$ quail (27.75 and 31.85\%), respectively. However, hematocrit concentration was significantly different at 75 days for quails housed at $102 \mathrm{~cm}^{2} /$ quail, whereas the other sampling times were similar.

The imposed stocking conditions was not the only factor influencing quail hematology (Table 1). We observed that the increase in ambient temperature up to $33.7^{\circ} \mathrm{C}$ at 75 days of sampling, with minimums of $18.9^{\circ} \mathrm{C}$, coincides with the period in which the highest hematocrit concentration was reported (Table 6). Although the maximum temperature reached $34.9^{\circ} \mathrm{C}$ at 100 days, the amplitude in this period $\left(16.9^{\circ} \mathrm{C}\right)$ was the largest (Table 1$)$. Therefore, it indicates that the minimum temperatures may have some compensating effect, promoting adaptation of quails to the imposed conditions.

In situations of acute environmental and/or thermal stress, physiological changes such as decreased blood viscosity, increased hematocrit and hematimetric indices, mean corpuscular hemoglobin and mean corpuscular hemoglobin concentration are typical in birds (Laganá et al., 2005; Yahav et al., 2007). The decreased viscosity can alter blood flow in vessels and reduce the distribution of blood to body tissues (Borges, 2001), which compromises quail performance.

Wein et al. (2017) evaluated the effects of cage size and different stocking densities in hens and observed increased hematocrit levels in high-density stocked animals as a response to stress.

The blood sampling time (period) at 25, 50, 75 days did not influence hemoglobin concentration of quails housed at stocking densities of 112.2, 102, 93.5, and $86.31 \mathrm{~cm}^{2} /$ quail. However, hemoglobin concentration was affected at 100 days of the experiment. Hemoglobin concentrations decreased with increasing time in quails housed under high-density conditions (93.5 and $86.31 \mathrm{~cm}^{2} /$ quail), with the lowest values for hemoglobin (10.45 and $9.13 \mathrm{~g} / \mathrm{dL}$ ), respectively. Evidence of adaptation in less adverse conditions was noted, i.e., more space per animal in cages (112.2 and $102 \mathrm{~cm}^{2} /$ quail). 
There was no significant difference between hemoglobin values $(\mathrm{g} / \mathrm{dL})$ in quails housed at $112.2 \mathrm{~cm}^{2} /$ quail, regardless of the sampling period $(25,50,75$, and 100 days). It demonstrates that other factors may have affected hemoglobin concentration over time.

Quails housed at $102 \mathrm{~cm}^{2} /$ quail had similar hemoglobin concentrations at 25, 75, and 100 days of the experiment. A significant difference was observed only at 50 days. It indicates that the effects of population stress were milder at this stocking density (102 $\mathrm{cm}^{2} /$ quail), and the animals adapted faster to imposed conditions. In turn, hemoglobin concentrations were similar at 100 days. This response was not observed in quails housed at 93.5 and $86.31 \mathrm{~cm}^{2} /$ quail since hemoglobin concentrations decreased significantly at 100 days to 10.45 and $9.13 \mathrm{~g} / \mathrm{dL}$, respectively. It is noteworthy mentioning that hemoglobin concentrations at 50 and 100 days were statically similar. In absolute values, the hemoglobin concentration at 100 days decreased compared to 50 days in quails housed at 93.5 and $86.31 \mathrm{~cm}^{2} /$ quail. It demonstrates that some external fact may have affected the adaptation of quails to conditions of high stocking density and time.

According to Bounous and Stedman (2000), the mean hemoglobin concentration in poultry (broilers and laying hens) is $9 \mathrm{~g} / \mathrm{dL}$, ranging from 7.0 to $13.0 \mathrm{~g} / \mathrm{dL}$. El-Kholy et al. (2017) reported that the mean hemoglobin in Japanese laying quails ranges from 8.99 to $11.80 \mathrm{mg}$. Moreover, Mohamed et al. (2015) reported that hemoglobin concentration ranged from 82 to $123 \mathrm{~g} / \mathrm{L}$ in a study evaluating the impacts of heat stress on quails' well-being, which differs from that observed in this experiment.

Relative to the $\mathrm{MCH}$, the time (period) of blood sampling at 25, 50, and 75 days of experiment was not influenced by stocking density $\left(112.2,102,93.5\right.$, and $86.31 \mathrm{~cm}^{2} /$ quail $)$. However, the mean corpuscular hemoglobin volume $(1.29 \mathrm{pg} / \mathrm{cell})$ in the last sampling period (100 days) was higher in quails housed at $102 \mathrm{~cm}^{2} /$ quail than in other treatments. It corresponds to an additional of $0.384,0.664$, and $0.606 \mathrm{pg} /$ cell compared with quails housed at $112.2,93.5$, and $86.31 \mathrm{~cm}^{2} /$ quail, respectively. It is noteworthy mentioning that the MCH decreased in the second sampling period (50 days) and then increased at 75 days of the experiment for all treatments $\left(112.2,102,93.5\right.$, and $86.31 \mathrm{~cm}^{2} /$ quail). Initially, the $\mathrm{MCH}$ had means of $0.809 \mathrm{pg} / \mathrm{cell}$, decreased to $0.522 \mathrm{pg} / \mathrm{cell}$, raised to $0.926 \mathrm{pg} / \mathrm{cell}$, and dropped again at 100 days $(0.876 \mathrm{pg} / \mathrm{cell})$.

Relative to the MCHC, the time (period) of blood sampling at 25 and 100 days of experiment was not influenced by stocking density $\left(112.2,102,93.5\right.$, and $86.31 \mathrm{~cm}^{2} /$ quail). However, the mean corpuscular hemoglobin concentration (64.41 $\mathrm{g} / \mathrm{dL}$ ) at 25 days was higher in quails housed at $86.31 \mathrm{~cm}^{2} /$ quail than in other treatments. The MCHC of quails housed at 112.2 $\mathrm{cm}^{2} /$ quail was similar at 25, 50,75, and 100 days. The MCHC of quails housed at $102 \mathrm{~cm}^{2} /$ quail was similar at 25 and 100 days (53.21 and $42.98 \mathrm{~g} / \mathrm{dL}$, respectively), and $50(31.11 \mathrm{~g} / \mathrm{dL})$ and $75(27.92 \mathrm{~g} / \mathrm{dL})$ days. The MCHC of quails housed at 93.5 $\mathrm{cm}^{2} /$ quail was similar at 25, 50, and 100 experimental days. It differs from quails housed at $86.31 \mathrm{~cm}^{2} /$ quail, in which similarity was reported at 50,75, and 100 experimental days.

The mean $\mathrm{H} / \mathrm{L}$ ratio was lower at 25 days (0.880) than at 100 days (1.219). Quails housed at $86.31 \mathrm{~cm}^{2} / q u a i l$ had lower mean $\mathrm{H} / \mathrm{L}$ ratio (0.961) compared with animals housed at $102 \mathrm{~cm}^{2} /$ quail. None of the treatments showed different estimates. Under conditions of extreme stress, birds can develop heteropenia and lymphocytosis. Thus, a two-phase cellular reaction may be present in poultry exposed to stress. This biphasic leucocytic response to stress may be unique to poultry (Campbell, 2004). Therefore, this reduction in heterophil counts may be related to the increase in lymphocyte count (lymphocytosis), which is associated with immune stimulation. Moreover, it is also associated with some types of heterophils under conditions of stress and disease, such as toxic heterophils, as seen in Figure 3. 
Figure 3. Photomicrograph of blood distension in Japanese quail showed heterophile in toxic form (arrow). Fast Panotic. 100x.

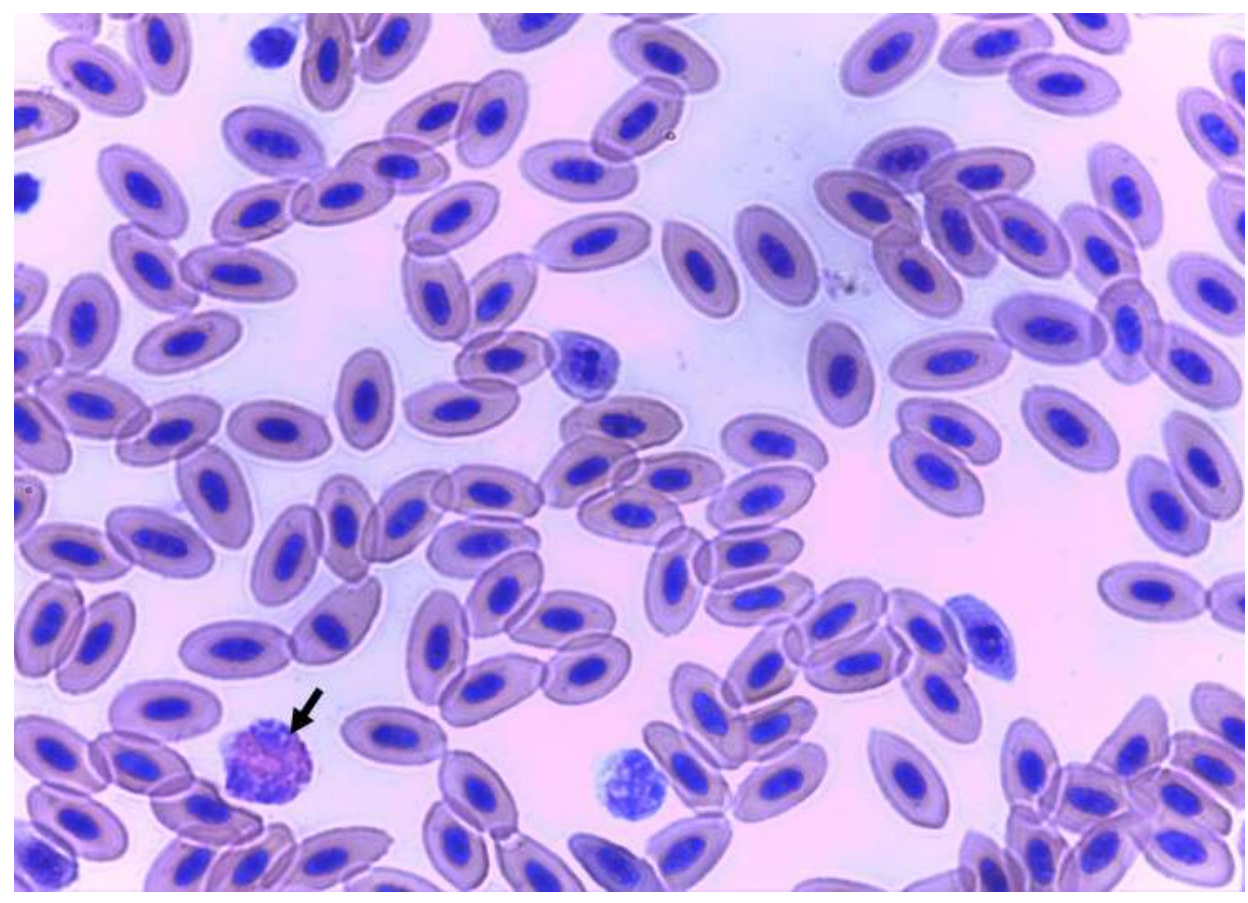

Source: Own research.

There is a relationship between stressful conditions and increased lymphocytic cells in quails. Some theories suggest that the increase in circulating lymphocytes depends on the demand of the tissues for lymphocytes. In response to circulating glucocorticoids, circulating lymphocytes bind to endothelial cells that line the walls of blood vessels, and migrate from the blood circulation to other tissues such as the spleen, lymph nodes, bone marrow, and skin, where they are rescued (Dhabhar, 2002). Scanes and Christensen (2014) observed no significant difference in differential leukocyte count and heterophil/lymphocyte ratio under conditions of moderate stress. This result differs from that found in the present study. On the other hand, other authors such as Rosa et al. (2011), Prieto and Campo (2010), and Soleimani et al. (2011) reported increased heterophil/lymphocyte ratio in birds under stress conditions. The $\mathrm{H} / \mathrm{L}$ ratio is a less variable stress indicator than individual cells, and it is more reliable than plasma corticosteroid levels. However, this rule applies only under mild and moderate stress (Gross and Siegel, 1983). The results showed that the heterophil/lymphocyte ratio increased over time.

The CTL was lowest $(14245 \mu \mathrm{L})$ during the last sampling period (100 days). With the experience of stress, leukocyte reserves tend to decline, and this effect has a profound influence on the number of leukocytes entering the blood circulation. According to Jain (1993), the reference values of leukocytes in poultry ranges from 12000 to 30000 leukocytes $/ \mathrm{mm}^{3}$.

The mean corpuscular volume or mean globular volume was significantly affected $(p=0.0001)$ by time. The MCV was significantly higher in the last sampling periods (75 and 100 days; 3,101 and $2,411 \mu \mathrm{m}^{3}$, respectively) compared to 25 and 50 days, which were statistically similar among each other. The present study does not agree with Porto et al. (2015), who observed that chronic heat stress does not interfere with the production of serum anti-Newcastle antibody titers in pre-starter and starter chicks. But corroborates with the findings of Souza et al. (2010) in a study with stress-induced laying hens. The $\mathrm{MCV}$ is used as an indicator of anemia in animals. 


\section{Conclusion}

Different stocking densities do not interfere with the performance and eggshell quality but affect the core and shin temperatures of Japanese quails. Hematological parameters and head temperature are affected by stocking density and time. High-density stocked Japanese quails exposed to prolonged stress can become chronically stressed. However much the quail tries to adapt to the adverse condition, the organism reaches exhaustion, which leads to severe consequences on physiological and behavioral parameters. The stocking density of $102 \mathrm{~cm}^{2} /$ quail is the most recommended because it does not differ from the control treatment.

\section{Acknowledgments}

I thank Capes for granting the scholarship, The company Vicami-SP® for the donation of Japanese quails and the company Granforte for the donation of part of the feed used during the experimente.

\section{References}

Albino, L. F. T., \& Barreto, S. L. T. (2003). Creation of quails for the production of eggs and meat. Learn Easy, 268p.

Araújo, W. A. G. \& Albino, L. F. T. (2011). Commercial incubation. Transworld Research Network, 105 -138.

Albino, L. F. T., Carvalho, B. R., Maia, R. C. \& Barros, V. R. S. M. (2014). Laying hens Raising and feeding. Ed. Learn Easy, 376p.

Bedánová, I., Voslarova, E., Chloupek, P., Pistekova, V., Suchy, P., Blahova, J., Dobsikova, R. \& Vecerek, V. (2007). Stress in broilers resulting from shackling. Poultry Science, 86(0), 1065-1069. 10.1093/ps/86.6.1065

Bounous, D. I., \& Stedman, N. (2000). Normal avian hematology: chicken and turkey. In: Feldman, B. F., Zinkl, J. G., Jain, N. C. Schalm's Veterinary Hematology. (5a ed.), Lippincott Williams \& Wilkins, 1147-1154.

Borges, S. A. (2001). Electrolyte balance and its interrelation with acid-base balance in broilers subjected to heat stress. Thesis (Doctorate in Zootechnics) Postgraduate Course in Zootechnics, Universidade Estadual Paulista. 97 p.

Calefi, A. S., Honda, B. T. B., Costola-de-Souza, C., Siqueira, A. de, Namazu, L. B., Quinteiro-Filho, W. M., Fonseca, J. G. da S., Aloia, T. P. A., PiantinoFerreira, A. J. \& Palermo-Neto, J. (2014). Effects of long-term heat stress in an experimental model of avian necrotic enteritis. Poultry Science, 93(6), 13441353. $10.3382 / \mathrm{ps} .2013-03829$

Campbell, T. W. (2004). Clinical Chemistry of Birds. In: Thrall, M.A. Veterinary Hematology and Clinical Chemistry, 479-492.

Castilho, V. A. R., Garcia, R. G., Lima, N. D. S., Nunes, K. C., Caldara, F. R., Nääs, I. A, Barreto, B. \& Jacob, F. G. (2015). Welfare of laying hens in different densities of housing. Brazilian Journal of Biosystems Engineering, 9(2), 122-131. http://dx.doi.org/10.18011/bioeng2015v9n2p122-131

Coles, E.H. (1984). Veterinary Clinical Pathology. (3a ed.), Ed Manole, 566p.

Dahlke, F., Gonzales, E., Gadelha, A. C., Maiorka, A., Borges, S. A., Rosa, P. S., Faria Filho, D. E. \& Furlan, R. L. (2005). Warping, hormone levels of triiodothyronine and thyroxine and body temperature of broilers of different genotypes reared under different temperature conditions. Rural Science, 35(3), 664-670. http://dx.doi.org/10.1590/S0103-84782005000300029

Dantzer, R. \& Kelly, K. W. (1989). Stress and immunity: an integral view of relationships between the brain and imune system. Life Sciences, 44(26), 19952008. 10.1016 / 0024-3205 (89) 90345-7

Dhabhar, F. S. (2002). A hassle a day may keep the doctor away: stress and the augmentation of immune function. Integrative and Comparative Biology, 42(3), 556-564. https://doi.org/10.1093/icb/42.3.556

Dhabhar, F. S. (2009). Enhancing versus suppressive effects of stress on immune function: implications for immunoprotection and immunopathology. Neuroimmunomodulation, 16(5), 300-317. 10.1159/000216188

Drabkin, D. (1948). The standardization of hemoglobin measurement. American Journal of Medical Science, 215(1), 110-111. 10.1097 / 00000441194801000-00017

Davis, A. K., Maney, D. L. \& Maerz, J. C. (2008). The use of leukocyte profiles to measure stress in vertebrates: a review for ecologists. Functional Ecology, 22(0), 760-772. 10.1111/j.1365-2435.2008.01467.x

El-Kholy, M. S., El-Hinestúpido, M. M., Alagai, M., El-Hack, M. E. A. \& El-Sayed, S. A. E. A. E. (2017). Dietary Supplementation of Chromium Can Alleviate Negative Impacts of Heat Stress on Performance, Carcass Yield, and Some Blood Hematology and Chemistry Indices of Growing Japanese Quail. Biological trace element research, 179(1), 148-157. 10.1007 / s12011-017-0936-Z

Fahey, A. G. \& Cheng, H. W. (2008). Group Size and Density Effects on Physical Indices and Cell-Mediated Immunity in Two Genetic Lines of White Leghorn Layers. Poultry Science, 87(12), 2500-2504. https://doi.org/10.3382/ps.2007-00407 
Gross, W. B. \& Siegel, H. S. (1983). Evaluation of the heterophil/ lymphocyte ratio as a measure of stress in chickens. Avian Diseases, 27(4), 972-979. $10.2307 / 1590198$

Guimarães, M. C. C., Furtado, D.A., Nascimento, J. W. B. do, Tota, L. C. A., Silva, C. M. \& Lopes, K. B. P. (2014). Effect of the season on the productive performance of quails in the semi-arid region of Paraíba. Brazilian Journal of Agricultural and Environmental Engineering, 18(2), 231-237. https://doi.org/10.1590/S1415-43662014000200015

Hillman, P. E., Scott, N. R. \& Van Thienhoven, A. (1982). Vasomotion in chicken foot: dual innervation of arteriovenous anastomoses. Animal Journal Physiology, 242(5), 582- 590. 10.1152 / ajpregu.1982.242.5.R582

Jain, N.C. (1993). Comparative hematologic features of some avian and mamalian species. In: JAIN, N.C. Essencials of veterinary haematology. Philadelphia: Lea \& Febiger, 54-71

Junqueira, L. C. \& Carneiro, J. (2004). Blood cells. In: Basic Histology. (10th ed.), Guanabara Koogan. Chapter 12. 223-237p.

Kodaira, V., Pereira, D. F, Soares, N. M. \& Bueno, L. G. F. (2015). Blood glucose concentration and heterophilic relationship: lymphocyte can be used as heat stress indicators for laying birds? Brazilian Journal of Biosystems Engineering, 9(2), 182-190. http://dx.doi.org/10.18011/bioeng2015v9n2p182-190

Laganá, C., Ribeiro, A. M. L., Gonzalez, F. H. D., Almeida Lacerda, L., Terra, S. R. \& Barbosa, P. R. (2005). Supplementation of organic vitamins and minerals in the biochemical and hematological parameters of broilers in heat stress. Animal Industry Bulletin, 62(2) 157-165.

Leandro, N. S. M., Vieira, N. S., Matos, M. S., Café, M. B., Stringhini, J. H. \& Santos, D. A. (2005). Productive Performance of Japanese Quails (Coturnix coturnix japonica) Subject to Different Densities and Types of Beak. Acta Scientiarum Animal Sciences, 27(1), 129-135. 10.4025/actascianimsci.v27i1.1263

Lima, H. J. D, Barreto, S. L. T, Valeriano, M. H, Vieira, D. V. G. \& Costa, S. L. (2012). Japanese quail housing density in the initial laying stage. Global Science and Technology, 5(2), 186-193.

Lopes, I. R. V., Fuentes, M. F. F., Freitas, E. R., Soares, M. B. \& Ribeiro, P. S. (2006). Effect of housing density and level of metabolizable energy of the diet on the zootechnical performance and characteristics of Japanese quail eggs. Agronomic Science, 37(3), 369-375.

Matteri, R. L., Carroll, J. A. \& Dyer, C. J. (2000). Neuroendocrine responses to stress. In: Moberg, G. P., Mench, J. A. The biology of animal stress. Oxon: CAB International. 43-76.

Nordstrom, J. O. \& Ousterhout, L. E. (1982). Estimation of shell weight and shell thickness from egg specific gravity and egg weight. Poultry Science, 61(10), 1991-1995. https://doi.org/10.3382/ps.0611991

On Așila, E. E. \& Aksoy, F. T. (2005).Stress parameters and immune response of layers under different cage floor and density conditions. Livestock Production Science, 95(3), 255-263. 10.1016/ j.livprodsci.2005.01.006

Pereira, D. F. Vitorasso, G., Oliveira, S. C., Kakimoto, S. K., Togashi, C. K. \& Soares, N. M. (2008). Correlations between thermal environment and egg quality of two layer commercial strains. Brazilian Journal of Poultry Science, 10(2), 81-88. http://dx.doi.org/10.1590/S1516-635X2008000200002

Porto, M. L., Givisiez, P. E. N., Saraiva, E. P., Costa, F. G. P., Moreira Filho, A. L. B., Andrade, M. F. S., Brandão, P. A. \& Guerra, R. R. (2015). Glutamic Acid Improves Body Weight Gain and Intestinal Morphology of Broiler ChickensSubmitted to Heat Stress. Brazilian Journal of Poultry Science, 17(3), 355362. https://doi.org/10.1590/1516-635x1703355-362

Quinteiro-Filho, W. M., Ribeiro, A., Ferraz-de-Paula, V., Pinheiro, M. L., Sakai, M., Sa, L. R., Ferreira, A. J. \& Palermo-Neto, J. (2010). Heat stress impairs performance parameters, induces intestinal injury, and decreases macrophage activity in broiler chickens. Poultry Sciece, 89(9), 1905-1914. 10.3382 / ps.2010-00812

Rauw, W. M. (2012). Immune response from a resource allocation perspective. Frontiers in Genetics, 3(0), 1-14. https://doi.org/10.3389/fgene.2012.00267

Richards, S. A. (1971). The significance of changes in the temperature of the skin and body core of the chicken in the regulation of heat loss. The Journal of Physiology, 216(1), 1-10. 10.1113/jphysiol.1971.sp009505

Rosa, G. A., Sorbello, L. A., Dittrich, R. L., Moraes, M. T. T. \& Oliveira, E. G. (2011). Hematological profile of Japanese quails (Coturnix japonica) under thermal stress. Rural Science, 41(9), 1-6.

Rostagno, H. S., Albino, L. F. T., Hannas, M. I., Donzele, J. L., Sakomura, N. K., Perazzo, F. G., Saraiva, A., Teixeira, M. V., Rodrigues, P. B., Oliveira, R. F., Barreto, S. L. T., \& Brito, C. O. (2017). Brazilian tables for poultry and swine: food composition and nutritional requirements. 4a edição. Viçosa, MG: Departamento de Zootecnia, Universidade Federal de Viçosa, 488p.

Sarica, M., Boga, S. \& Yamak, U. S. (2008). The effects of space allowance on egg yield, egg quality and plumage condition of laying hens in battery cages. Czech Journal Animal Science, 53(8), 346-353. 10.17221 / 349-CJAS

SAS - Statistic Alanalysis System: Realease 9.1.3 (software). Cary: Sas Institute, 2009. 620 p.

Scanes, C. G. \& Christensen, K. (2014). Comparison of meta-analysis of the hematological parameters of commercial and indigenous poultry to wild birds: implications to domestication and development of commercial breeds/lines. Journal Veterinary Science Animal Health, 1: 6-13. 10.5897 / JVMAH

Scanes, C. G. (2016). Biology of stress in poultry with emphasis on glucocorticoids and the heterophil to lymphocyte ratio. Poultry Science, 95(9), 2208-2215. https://doi.org/10.3382/ps/pew137

Schmidt, E. M. S., locatelli-dittrich, R., Santin, E. \& Paulillo, A. C. (2007). Clinical pathology in poultry: a tool to monitor poultry health - review. Archives of Veterinary Science, 12(3), 09-20. http://dx.doi.org/10.5380/avs.v12i3.10906 
Research, Society and Development, v. 10, n. 3, e54410313686, 2021

(CC BY 4.0) | ISSN 2525-3409 | DOI: http://dx.doi.org/10.33448/rsd-v10i3.13686

Shini, S., Kaise, P., Shini, A. \& Bryden, W. L. (2008). Differential alterations in ultrastructural morphology of chicken heterophils and lymphocytes induced by corticosterone and lipopolysaccharide. Veterinary Immunology and Immunopathology, 122(1-2), 83-93. 10.1016/ j.vetimm.2007.10.009

Shini, S., Huff, G. R., Shini, A. \& Kaiser, P. (2010). Understanding stress-induced immunosuppression: Exploration of cytokine and chemokine gene profiles in chicken peripheral leukocytes. Poultry Science, 89(4), 841-851. https://doi.org/10.3382/ps.2009-00483

Silva, R. M., Furlan, A. C., Ton, A. P. S., Martins, E. N., Scherer, C., Murakami, A. E. (2009). Nutritional requirements for calcium and phosphorus in growing cutting quails. Revista Brasileira de Zootecnia, 38(8), p.1509-1517.

Soares, D. F., Pizzolante, C. C, Duarte, K. M. R, Moraes, J. E, Budiño, F. E. L, Sores, W. V. B. \& Kakimoto, S. K. (2018). Welfare indicators for laying Japanese quails caged at different densities. Annals of the Brazilian Academy of Sciences, 90(4), 3791-3797. https://doi.org/10.1590/0001-3765201820180276

Soleimani, A. F., Zulkifli, I., Omar, A. R. \& Raha, A. R. (2011). Physiological responses of 3 chicken breeds to acute heat stress. Poultry Science, 90(7), 14351440. 10.3382 / ps.2011-01381

Souza Júnior, J. B. F., Queiroz, J. P. A. F., Domingos, H. G. T., Torquato, J. L., Sá Filho, G. F. \& Costa, L. L. M. (2013). Thermographic evaluation of Japanese quails (Coturnix coturnix japonica). Journal of Animal Behaviour and Biometeorology, 1(2), 61-64. 10.14269/2318-1265.v01n02a05

Souza, K. M. R., Carrijo, A. S., Allaman, I. B., Fascina, V. B., Mauad, J. R. C. \& Suzuki, F. M. (2010). Alternative methods of food restriction in forced laying of commercial laying hens. Revista Brasileira Zootecnia, 39: 356-362.

Thrall, M. A., Baker, D. C., Campbell, T. W., Denicola, D., Fettman, M. J., Lassen, E. D., Rebar, A. \& Weiser, G. (2006). Hematology and veterinary clinical biochemistry. Scientific review José Jurandir Fagliari, translation José Jurandir Fagliari, Diogo Scuta Fagliari, Diogo Scuta Fagliari. São Paulo, Roca, 581.

Vercese, F., Garcia, E. A., Sartori, J. R., Silva, A. de P., Faitarone, A. B. G., Berto, D. A., Molino, A. B. \& Pelícia, K. (2012). Performance and egg quality of Japanese quails submitted to cyclic heat stress. Brazilian Journal of Poultry Science, 14(1), 37-41. 10.1590 / S1516-635X2012000100007

Voigt, G. L. 2003. Hematological Techniques and Techniques for Veterinary Technicians. Zaragoza, Editorial ACRIBIA, 144p.

Wein, Y., Shira, E. B. \& Friedman, A. (2017). Avoiding handling-induced stress in poultry: use of uniform parameters to accurately determine physiological stress. Poultry Science, 96(1), 65-73. 10.3382/ ps / pew 245

Yahav, S. (2007). Thermal manipulation during the perinatal period-does it improve thermotolerance and performance of broiler chickens? Proceedings of the 19th Australian Poultry Science Symposium, Sydney, New South Wales, Australia, 12-14 February 2007. Poultry Research Foundation, Australian. 